\title{
Attitudes to Marriage and Childbearing
}

\section{Ekaterina Hertog}

Over the past several decades Japanese society has experienced significant shifts in family formation trends. Of particular interest for this chapter are marriage and childbearing delays, increased rates of divorce, rising rates of lifelong singlehood, growth in childlessness rates, and fertility rates falling far below two children per woman. These have occurred although the large majority of unmarried men and women say that they intend to marry at some point, few people explore alternative partnership forms, few express a desire to remain childless, almost all children are born within marriages, and the large majority of men and women state that they want to have two children (NIPSSR 2015).

The limited attitudinal change against the background of major behavioural shifts presents us with a puzzle. Aiming to make sense of it, this chapter will discuss current research on marriage and childbearing attitudes and relate them to the realities of marriage and childbearing in contemporary Japan. My two primary goals in this chapter are (a) to describe the attitudes to marriage and childbearing in Japan, noting continuities and changes; and (b) to summarise the conflicting material and normative pressures associated with marriage, and how these are reflected in men's and women's attitudes to it.

Marriage remains the only socially and normatively sanctioned way of having children in Japan (Hertog 2009) and the link between the two has been strengthening in the past years: more people think of children as the main benefit of marriage and a growing number of couples marry only after conceiving a child (NIPSSR 2015). Consequently, this chapter will discuss attitudes to marriage and childbearing together, as the two are intimately linked by the widespread assumption that a marriage will be shortly followed by children. 


\section{Theoretical framework}

Much of the prior research on changes in family formation relies on the second demographic transition (SDT) theory. This theory argues that growing individualisation of attitudes to family formation is the core factor behind withdrawal from marriage and diversification of families in developed countries (e.g. Lesthaeghe 1983). The proponents of the SDT framework argue that it is universally applicable (e.g. Lesthaeghe 2014), though the evidence from East Asia, especially Japan, has not been fully consistent with its claims (e.g. Lee et al. 2010). This framework expects continuous liberalisation and individualisation of attitudes, although it concedes that the pace of change may be different depending on the cultural and structural legacy in a given society.

Indicating a potential shortcoming in the general applicability of the SDT framework, Lee, Tufis and Alwin (2010: 186) argue that economic and socio-institutional environment influence not only the pace, but also the direction of change when it comes to attitudes to gender equality in Japan. In a marked departure from the SDT predictions, Lee et. al. find that while views about the consequences of women's labour market participation and gender ideology have become more egalitarian between 1994 and 2002 in Japan, beliefs about the importance of women's work have become more conservative. They attribute the traditional attitudes to women's work to the persistent tax disincentives to women's employment, limited career opportunities available to women, lack of affordable childcare, and professionalisation of the housewife role. At the same time Lee, Tufis and Alwin report that both men and women have become more accepting of women's earnings and the change has been particularly rapid for men, potentially reflecting the economic reality that makes the sole breadwinner role onerous. In a similar challenge to the predictions of the SDT framework, this chapter argues that in Japan marriage remains a "package" of gender-specific 
expectations and obligations structured and reinforced by the normative and institutional environment (Bumpass et al. 2009) and is evaluated as such.

To explain the links between the labour market and welfare context and the attitudes to marriage and childbearing this chapter will draw on the work of McDonald (McDonald 2000; 2013) and Oppenheimer, Kalmjin, and Lim (1997). McDonald's gender equity theory emphasizes the conflict between the growing opportunities open to women outside families and the homemaker role they are expected to play after marriage. This conflict shapes, among other things, their attitudes and transitions to marriage and childbearing. I will use Oppenheimer, Kalmijn, and Lim's work to extend McDonald's approach to men. I will describe the way the conflict between casting men as main breadwinners despite shrinking labour market opportunities makes traditional marriages seem undesirable or out of reach to many Japanese men.

Locating men's and women's marriage and childbearing attitudes within the changing social context, I will demonstrate how the persistently gendered expectations associated with family formation have become unattractive to well-educated young men and women as well as untenable in a growing proportion of partnerships. The declining desirability and feasibility of the Japanese "marriage package" and the dearth of viable alternatives to it explains, in my view, the paradox of withdrawal from family formation against the high desirability of marriage and childbearing in Japan today.

Existing research on marriage attitudes primarily focuses on women, as their expanding access to education and employment is believed to make traditional marriage and family arrangements unattractive to them. The same arrangements are seen as beneficial or even essential to men (e.g. Kaufman and Goldscheider 2007), and therefore men's desire for traditional gendered marriage often remains unquestioned. Research highlighting the difficulties of being the sole breadwinner in a modern economy, however, questions these 
assumptions (Oppenheimer 2003; Oppenheimer et al. 1997). This overview will therefore give equal weight to men's and women's attitudes.

\section{Marriage and childbearing in postwar Japan}

As indicated in the introduction, Japanese marriage and childbearing behaviours shifted dramatically between the 1970 s and 2015 , with the pace of change accelerating from the mid1980s to the early 1990s. The average age of first marriage has risen from 27 to 31 for men and from 24 to 29 for women, while the total fertility rate fell from 2.13 to 1.45 between 1970 and 2015. Among 50-year-old men in 2015, 23 per cent have never been married, up from 1.7 per cent in 1970, when marriage was virtually universal. This change is all the more dramatic in Japan where singlehood almost invariably means childlessness. Unlike singlehood in other post-industrialised countries where young people are increasingly opting for alternative partnership forms, in Japan singlehood often entails "effective singlehood" that involves celibacy and lack of social interaction with members of the opposite sex in general (Jones 2007).

Table 1 Marriage and childbearing trends

\begin{tabular}{|c|c|c|c|c|c|c|}
\hline Year & TFR $^{\text {b) }}$ & $\begin{array}{l}\text { Mean age first } \\
\text { marriage }^{\text {b) }}\end{array}$ & $\begin{array}{l}\text { Mean } \\
\text { age at } \\
\text { first } \\
\text { birth b) }\end{array}$ & $\begin{array}{l}\text { Children } \\
\text { born } \\
\text { within } 3 \\
\text { years of } \\
\text { marriage } \\
\text { b) } \\
\quad(\%)\end{array}$ & $\begin{array}{l}\text { Never married by } \\
50 \text { a) } \\
(\%)\end{array}$ & $\begin{array}{l}\text { Children } \\
\text { born } \\
\text { outside } \\
\text { marriage } \\
\text { b) } \\
\qquad \%)\end{array}$ \\
\hline
\end{tabular}




\begin{tabular}{|l|l|l|l|l|l|l|l|l|}
\hline & & Men & Women & Women & & Men & Women & \\
\hline 1970 & 2.13 & 26.9 & 24.2 & 25.6 & 89.1 & $1.7 \%$ & 3.33 & 0.93 \\
\hline 1975 & 1.91 & 27 & 24.7 & 25.7 & 90.5 & 2.12 & 4.32 & 0.8 \\
\hline 1980 & 1.75 & 27.8 & 25.2 & 26.4 & 88.7 & 2.6 & 4.45 & 0.8 \\
\hline 1985 & 1.76 & 28.2 & 25.5 & 26.7 & 88.6 & 3.89 & 4.32 & 0.99 \\
\hline 1990 & 1.54 & 28.4 & 25.9 & 27.0 & 87.2 & 5.57 & 4.33 & 1.07 \\
\hline 1995 & 1.42 & 28.5 & 26.3 & 27.5 & 84.5 & 8.99 & 5.10 & 1.24 \\
\hline 2000 & 1.36 & 28.8 & 27 & 28.0 & 82.2 & 12.57 & 5.82 & 1.63 \\
\hline 2005 & 1.26 & 29.8 & 28 & 29.1 & 77.6 & 15.96 & 7.25 & 2.03 \\
\hline 2010 & 1.39 & 30.5 & 28.8 & 29.9 & 76 & 20.14 & 10.61 & 2.15 \\
\hline 2015 & 1.45 & 31.1 & 29.4 & 30.7 & 73.1 & 23.37 & 14.06 & 2.29 \\
\hline
\end{tabular}

Sources: a) (Statiatics Bureau, various years)

b) (MHLW, various years)

As a result, later and fewer marriages mean fewer children that tend to be born later. The spacing between children has also lengthened. In the 1970s almost 90 per cent of all children were born within 3 years after marriage. By 2015, this figure had fallen to 73 per cent. The link between marriage and childbearing, however, has remained strong throughout these years with only 2.29 per cent of children born outside marriage in 2015, up from 0.93 per cent in 1970.

These family formation trends take place against the background of high gender inequality in the public and in the domestic spheres. While the gender gap in education has almost closed, gender inequality in the labour market is pervasive. Women continue to form the bulk of precarious labour, there is a persistent gender gap in wages, maternal employment rates remain low, there are few female senior managers, and virtually no women on company 
boards (Estévez-Abe 2013; Nemoto 2016; Yu 2009). In 2017 Japan ranked 114 ${ }^{\text {th }}$ out of 144 countries in the Global Gender Gap Report, a testament to its low levels of gender equality.

Starting in the 1990s the Japanese state has made significant improvements regarding policies aimed at encouraging equal employment opportunities for both men and women and to help parents (mostly mothers) to combine work and family. Yet the effectiveness of such policies has been limited (Brinton and Mun 2016). In 2003 Japan ranked lowest among 33 countries in terms of public childcare availability (Fuwa and Cohen 2007), and wives there shouldered the largest proportion of housework. In 2015 The Economist rated Japan as the third worst economy in which to be a working mother in the OECD (The Economist Data Team 2016). In Japan it is still common for women to quit full-time jobs upon childbearing and return to the labour market only several years later, often into dead-end jobs. Women's limited career opportunities are related to the heavy demands of the "second shift," as wives continue to be responsible for virtually all housework and care work in married couples (Hertog, Kan, Shirakawa, and Chiba 2018), and the norms of intensive maternal investment in children remain strong (e.g. Allison 2000). Consequently, married women with children still have to rely on their husbands' earnings as their own careers remain precarious and marriage and childbearing tend to be followed by numerous new responsibilities.

At the same time, the bursting of Japan's economic bubble has meant that men's ability to be the sole providers in their families has diminished. Over the past two decades, the average income of even full-time employed men as well as the number of full-time jobs available to recent graduates fell, while unemployment rates for young men and long-term unemployment among these men have gone up (Brinton 2011; Genda and Hoff 2005; MHLW 2013). Women's improved educational attainment and increasing labour-market participation have also meant that marriages with similar or higher status men are harder to achieve. The female preferences for "marrying up" (Raymo and Iwasawa 2005; Shirahase 
2014) mean that men with low qualifications are at a particular disadvantage in the marriage market (Raymo and Iwasawa 2005).

Table 2 Trends in social and economic indicators in Japan

\begin{tabular}{|c|c|c|c|c|c|c|c|}
\hline \multirow[t]{2}{*}{ Year } & \multicolumn{2}{|c|}{$\begin{array}{l}\text { Enrolment in 4-year } \\
\text { university degrees b) } \\
(\%)\end{array}$} & $\begin{array}{l}\text { Labour } \\
\text { force } \\
\text { participation } \\
\text { rate }^{\text {a) }}\end{array}$ & \multicolumn{2}{|c|}{$\begin{array}{l}\text { Percent working } \\
\text { in irregular jobs b) }\end{array}$} & $\begin{array}{l}\text { Gender } \\
\text { wage gap } \\
\text { (for regular } \\
\text { employees) b) }\end{array}$ & $\begin{array}{l}\text { Percent of } \\
\text { Housework } \\
\text { contribution } \\
\text { c) }\end{array}$ \\
\hline & Men & Women & $\begin{array}{l}\text { Women } \\
(15-64)\end{array}$ & Women & Men & & Men \\
\hline 1970 & 27.3 & 6.5 & 53.4 & & & & \\
\hline 1975 & 41 & 12.7 & 49.7 & & & & \\
\hline 1980 & 39.3 & 12.3 & 52.5 & & & & \\
\hline 1985 & 38.6 & 13.7 & 54.5 & & & & \\
\hline 1990 & 33.4 & 15.2 & 57.1 & 38.1 & 8.8 & 60.2 & \\
\hline 1995 & 40.7 & 22.9 & 58.4 & 39.1 & 8.9 & 62.5 & \\
\hline 2000 & 47.5 & 31.5 & 59.6 & 46.4 & 11.7 & 65.5 & 1998: 11.3 \\
\hline 2005 & 51.3 & 36.8 & 60.8 & 52.5 & 17.7 & 65.9 & 2003: 13.5 \\
\hline 2010 & 56.4 & 45.2 & 63.2 & 53.8 & 18.9 & 69.3 & 2008: 14.5 \\
\hline 2015 & 55.4 & 47.4 & 66.7 & 56.3 & 21.9 & 72.2 & 2013: 14.9 \\
\hline
\end{tabular}

Sources: a) (OECD 2017)

b) (Gender Equality Bureau 2017)

c) (NIPSSR 2013)

These socio-economic changes make traditional marriages, where a wife becomes a homemaker while the husband is the main or even the only breadwinner, impractical and often impossible. Yet, as women continue to face obstacles to combining careers with 
families, no clear alternative to the traditional marriage script has emerged, leading to a "drift into singlehood" (Schoppa 2006; Yoshida 2016).

\section{Attitudes to marriage}

The Second Demographic Transition theory expects women's greater participation in the public sphere and withdrawal from marriages and childbearing in Japan to be connected via the individualisation of attitudes to family formation. For example, Bumpass, Rindfuss, Choe, and Tsuya write "As the tension continues to build between traditional expectations and changing behaviours, Japanese attitudes are increasingly accepting of behaviours once strongly disapproved, and marriage and childbearing are increasingly being seen as discretionary" (2009: 229; see also Lesthaeghe 2014).

Table 3 Attitudes to marriage and childbearing

\begin{tabular}{|c|c|c|c|c|c|c|}
\hline & \multicolumn{2}{|c|}{ Plan to marry one day a) } & \multicolumn{2}{|c|}{$\begin{array}{l}\text { It is not desirable to } \\
\text { spend one's life staying } \\
\text { single a) }\end{array}$} & \multicolumn{2}{|c|}{$\begin{array}{l}\text { Once married one } \\
\text { should not divorce just } \\
\text { because of character } \\
\text { incompatibility a) }\end{array}$} \\
\hline Year & Men & Women & Men & Women & Men & Women \\
\hline 1987 & 91.8 & 92.9 & & & & \\
\hline 1992 & 90 & 90.2 & 65.3 & 57.6 & 68 & 57 \\
\hline 1997 & 85.9 & 89.1 & 57.7 & 49.1 & 62 & 47 \\
\hline 2002 & 87 & 88.3 & 60.9 & 53 & 66 & 53 \\
\hline 2005 & 87 & 90 & 64 & 56 & 69.0 & 58.3 \\
\hline 2010 & 86.3 & 89.4 & 64 & 57 & 72.3 & 62.2 \\
\hline 2015 & 85.7 & 89.3 & 64.7 & 58.2 & 69.2 & 59.7 \\
\hline
\end{tabular}




\begin{tabular}{|l|l|l|l|l|l|}
\hline & \multicolumn{2}{|l|}{} & \multicolumn{2}{l|}{} \\
& \multicolumn{2}{|l|}{ If a couple lives together } & \multicolumn{2}{l|}{ A married couple should } & Desired number of \\
& a) & & \multicolumn{2}{l|}{ (hildren b) } \\
\hline & Men & Women & Men & Women & \\
\hline 1987 & & & & & 2.23 \\
\hline 1992 & 78.5 & 72.6 & 88 & 85 & 2.18 \\
\hline 1997 & 69.0 & 59.3 & 78 & 71 & 2.16 \\
\hline 2002 & 71.6 & 60.3 & 76 & 69 & 2.13 \\
\hline 2005 & 73.9 & 62.9 & 79 & 69 & 2.11 \\
\hline 2010 & 73.5 & 67.4 & 72.3 & 62.2 & 2.07 \\
\hline 2015 & 74.7 & 70.5 & 75.4 & 67.4 & 2.01 \\
\hline
\end{tabular}

Note: a) Single men and women aged 18-34

b) Married men and women less than 50 years of age

Sources: (NIPSSR 2005, 2010, 2015)

As expected within the SDT framework, marriage in postwar Japan has been redefined as a matter of personal choice. Arranged marriages are rare have become rare, more people agree with the statement that "marriage is not absolutely necessary," and progressively fewer people see social acceptance as one of the benefits of the married state (MHLW 2013: 61, 70, 73; NIPSSR 2015). In spite of this ostensible freedom, changes in other attitudes and plans towards family formation have at most been moderate (see also Kamano 2013). The desire to get married remains high and most couples state that they would like to have more than 2 children. A number of marriage and family attitudes have experienced U-turns. In 2015 roughly as many people as in 1992 agreed that remaining single for life is not a good life choice, that divorce is a step not to be taken for such a simple reason as character 
incompatibility, and that if a couple lives together, they should get married (see Table 3).

There is no evidence that cohabitation is becoming a viable alternative to marriage as a majority of men and women believe children should be born within marriages (NIPSSR 2015). Cohabitation with a loved one, having a family, and having children were the top three reasons for getting married cited by men and women in 2014 (MHLW 2014). Fewer people believe that a married couple has to have children, but the proponents of this view still form a large majority of single men and women.

The one sphere where we see a major change is the belief that used to consign women to the home after marriage. This belief has weakened substantially, especially the perception that after marriage the husband should work while the wife should focus on the household. This view was supported by 60 per cent of unmarried men and 50 per cent of unmarried women in 1992 but is now espoused by only about 30 per cent of single men and women.

Table 4. Expectations of marriage

\begin{tabular}{|c|c|c|c|c|c|c|c|c|}
\hline \multirow[t]{2}{*}{ YEAR } & \multicolumn{2}{|c|}{$\begin{array}{l}\text { Even after } \\
\text { marriage one } \\
\text { should have their } \\
\text { own goals }\end{array}$} & \multicolumn{2}{|c|}{$\begin{array}{l}\text { It is natural to } \\
\text { sacrifice half of } \\
\text { one's } \\
\text { individuality and } \\
\text { way of life after } \\
\text { marriage }\end{array}$} & \multicolumn{2}{|c|}{$\begin{array}{l}\text { After marriage } \\
\text { the husband } \\
\text { should work } \\
\text { outside and the } \\
\text { wife should take } \\
\text { care of the } \\
\text { household }\end{array}$} & \multicolumn{2}{|c|}{$\begin{array}{l}\text { When the } \\
\text { children are } \\
\text { small the wife } \\
\text { should not work }\end{array}$} \\
\hline & Men & Women & Men & Women & Men & Women & Men & Women \\
\hline 1972 & & & & & $83^{a)}$ & $84^{\text {a) }}$ & & \\
\hline 1992 & 76.4 & 78.3 & 44.7 & 36.4 & 61.7 & 49.7 & 87.5 & 87.4 \\
\hline 1997 & 76.5 & 80.3 & 45.9 & 32.6 & 45.8 & 31.5 & & \\
\hline 2002 & 77.3 & 81.3 & 51.8 & 35.4 & 40.3 & 28.9 & 76.4 & 77.1 \\
\hline
\end{tabular}




\begin{tabular}{|l|l|l|l|l|l|l|l|l|}
\hline 2005 & 80.2 & 84.9 & 56.7 & 40.1 & 36.2 & 28.7 & 75.9 & 77.8 \\
\hline 2010 & 81.2 & 82.4 & 58.2 & 45.4 & 36.0 & 31.9 & 73.3 & 75.4 \\
\hline 2015 & 83.8 & 88.4 & 59.3 & 47.2 & 30.7 & 28.6 & 69.8 & 73.0 \\
\hline
\end{tabular}

Sources: a) Retherford, Ogawa, and Sakamoto (1996)

Everything else (NIPSSR 2005, 2010, 2015)

The traditional division of labour within married families is becoming less desirable and less expected. The majority of singles would like to form families where the wife either quits her job temporarily and then returns to the labour market, or where husband and wife both pursue their careers throughout their married lives. In 201573 per cent of women said that this would be an ideal life course after marriage, with 64 per cent of single women planning to achieve such an arrangement. 74 per cent of men would like to have working wives (NIPSSR 2015).

Figure 1. Women's perceptions of ideal work-life balance arrangements after marriage

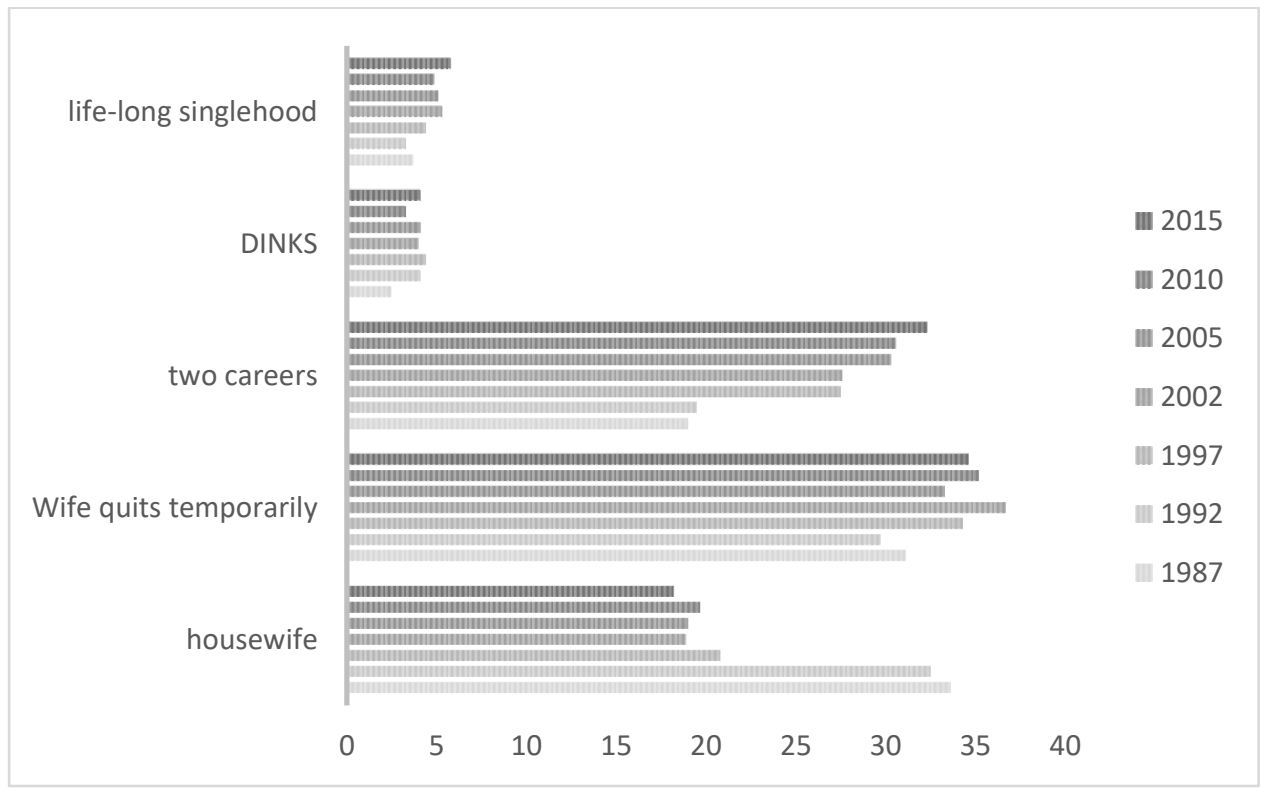

Figure 2. Work-life balance actually expected by women after marriage 


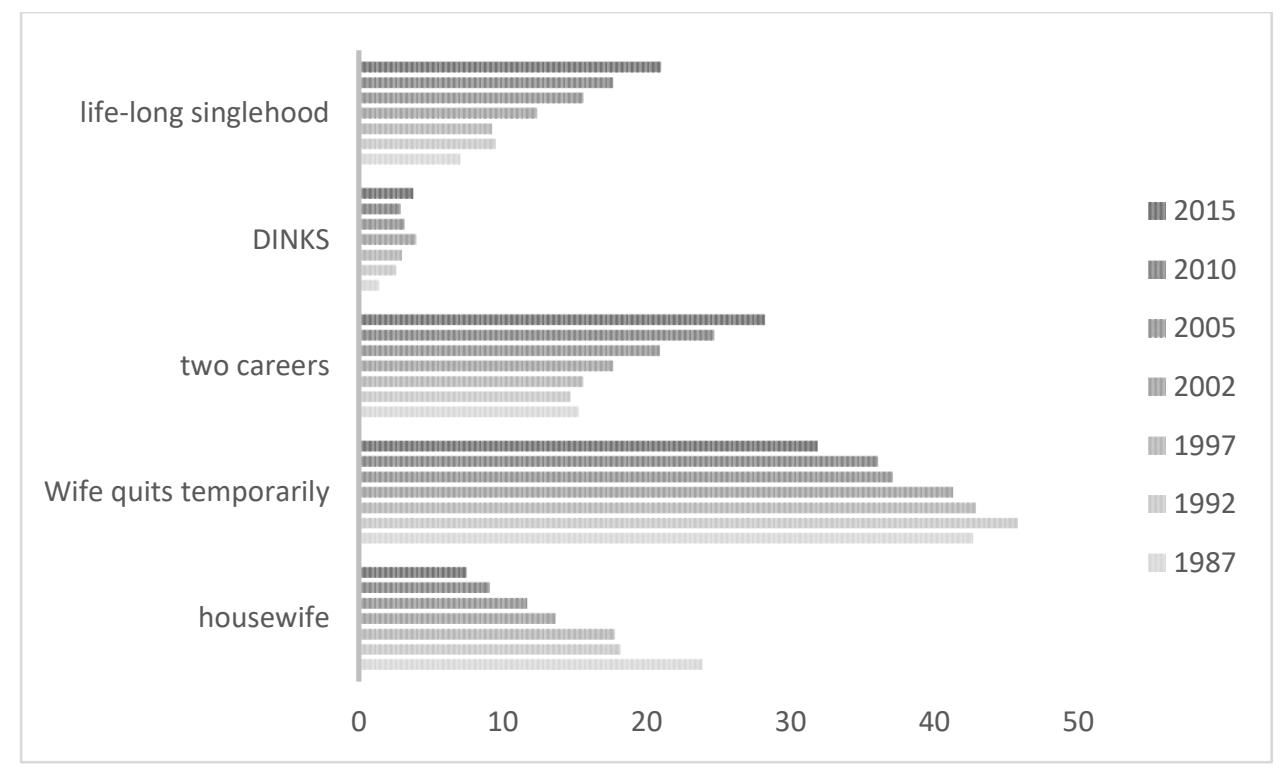

\section{Figure 3. Work-life balance desired by men after marriage}

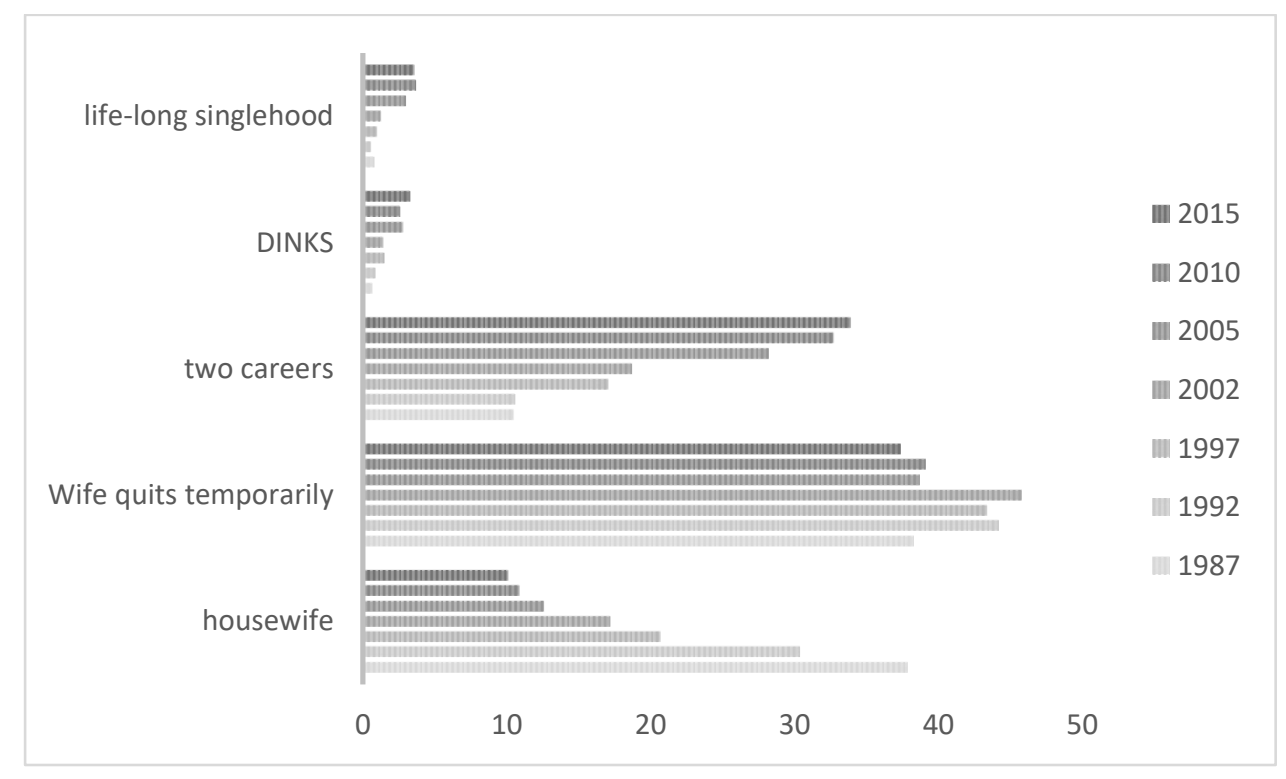

Sources: (NIPSSR 2005, 2010, 2015)

Women's preference for becoming housewives after marriage or childbearing stopped falling in 1997, possibly reflecting their continuously high levels of contribution to housework and childrearing (see Table 2). The proportion of men and women who believe that mothers rather than anyone else should take care of young children fell but is still close to 70 per cent for both genders. The economic reality, however, meant that women's expectation to be able 
to be housewives continued to fall, with only 7.5 per cent of women expecting to become housewives in 2015 .

Men's attitudes to their future wives' labour market participation changed even faster and more dramatically than women's own views between 1987 and 2015. While women were less likely than men to support gender specialisation within marriage in the 1980s and 1990s (Raymo and Iwasawa 2008), the situation had reversed by 2015 (see also Lee et al. 2010). In 2015 only around 10 per cent of men felt that having a non-working wife was desirable, fewer men than women believed that when children are small their mother should not work, and the difference in the proportion of men and women agreeing with the statement "after marriage the husband should work outside and the wife should take care of the household" has narrowed to 2 per cent, down from 12 per cent in 1992. Moreover, several studies have found a positive association between women's earning power and their progression to marriage in recent cohorts (N. Fukuda 2016: 69-70; S. Fukuda 2013), suggesting that these women are in demand in the marriage market. This change in relative attitudes seems to reflect men's growing unwillingness to be the only earners and women's increased scepticism about their ability to balance work and family responsibilities in the absence of meaningful help from their husbands at home. I will discuss these two mechanisms in the following sections.

\section{The importance of earning power}

While single-earner families are a rarity in today's Japan, husbands are still expected to be the main breadwinners, and a life-course where the wife quits her job temporarily to focus on the household while the children are young is still the most expected and the most desired arrangement (see Figures 1-3). The traditional division of labour is reinforced through extended family, marriage websites (Dalton and Dales 2016), popular culture (Matanle, 
Ishiguro, and McCann 2014), the press (Bobrowska and Conrad 2017), state policies (OECD 2015), and company practices (Nagase and Brinton 2017).

In this environment, young men who have not secured regular full-time employment status are at an extreme disadvantage. Cook (2014) demonstrates that these men wish to get married but feel they cannot do so unless they change their employment status . Following the traditional gender script, these men are adamant "though often conflicted-that on marriage men have to become the main breadwinner" (Cook 2013: 38). Using a survey of 10,000 regular and non-regular unmarried male employees, Uchino, Iijima, and Takahashi (2013) report that these men have similar perceptions about marriage and family, but nonregular employees are passive when it comes to pursuing marriage and this attitude is associated with their anxiety about employment and income status in the future (see also NIPSSR 2015).

Such attitudes are reinforced by these men's current or prospective female partners (Cook 2013; Honda 2002). In Cook's study women, irrespective of their own employment status, "made it clear that whilst they might date a man in irregular employment they would not marry or live with him unless he found stable work, regardless of their feelings" (2013: 38). An irregular job was seen as a sign of irresponsibility and incomplete transition to adulthood for men. Moreover, in a reflection of women's own precarious labour market position, a marriage to a man who cannot assume financial responsibility for a family and may lose his job at short notice was perceived as too risky. Finally, many women felt that their parents would never allow such a match. The highly gender-unequal labour market environment remains unfavourable to women (Genda and Hoff 2005). It hence makes securing livelihood via traditional marriage a more straightforward choice for women than trying to maintain a career and be breadwinners in their own right (Mirza 2016). This reality may be behind the reversal in the liberalisation trends in many marriage-related attitudes recorded in Table 3. 
Lower income and less stably employed men are therefore withdrawing from marriage faster than any other men (Piotrowski, Kalleberg, and Rindfuss 2015). Better earning men and women are also withdrawing from marriages but at a slower pace. Existing research indicates that the latter trend is associated with strongly prescribed gender roles within marriages, namely, reduction of personal freedom and autonomy in marriages.

\section{Work-life balance and perceived lack of freedom after marriage}

More than 80 per cent of single men and women in Japan believe that even after marriage individuals should be able to pursue their own goals (Table 4). In reality, however, they expect restrictions of their freedom and individuality after marriage, an expectation that has strengthened between 1992 and 2015. Unmarried men in regular employment see marriage as a constraint on their autonomy and free time, which are already limited by their often long working hours and work-centred lives (MHLW 2014; Nemoto, Fuwa, and Ishiguro 2013). There is somewhat more pressure on men to participate in family life, as around 80 per cent of wives said they believe that their husbands should share housework and childcare load with them in 2013, up from 74 per cent in 1993. Around 30 per cent of wives reported actively expecting men to help and 48 per cent expressed their dissatisfaction with the level of men's involvement in domestic work (NIPSSR 2013).

In reality men contributed around 14 per cent of total time spent on housework by the couple and around 20 per cent of time spent on childcare (NIPSSR 2013). The rate of increase of husbands' contributions to domestic work has been glacial (Table 2). The mismatch between desire for greater equality at home and the persistently unequal reality is becoming an additional source of stress for regularly employed married men, who feel they should participate more in family life, but cannot do so because of their busy schedules (Taga 2017). 
As men's working hours remain long, the main responsibility for domestic work falls onto women (e.g. Hidaka 2010; Nemoto 2008). Acess to childcare has made balancing work and family easier for women who work only part time and are able to secure a place in a nursery, but it the total paid and unpaid workload worse for women in full-time employment (Hertog 2018). Nursery waiting lists also remain long (Japanese Economy Information Division 2005; MHLW 2016). Moreover, there is no formal help available for much more time-intensive housework responsibilities. As a result, for women, marriage and childbearing are associated with loss of financial autonomy and a dramatic increase in domestic workload (MHLW 2014; Mirza 2016; Nemoto 2008). Women's growing ambivalence about their caregiver roles was evident in a Mainichi Newspaper report on "The Japanese Population" (2000). According to this report, Japanese women's belief that children taking care of aged parents is a "good custom" or a "natural duty" has been falling since the 1980s (N. Fukuda 2016: 52). Women are also "voting with their feet" by having fewer children with husbands who do not help at home (Nagase and Brinton 2017) and avoiding marriages associated with particularly heavy care burdens (Yu and Hertog 2018). Fuwa (2014) directly links the incompatibility of work and family life in Japan with highly educated women's negative attitudes to marriage.

Given the realities of the Japanese labour market, men and women find it difficult to envisage a non-traditional division of labour in their future families and end up perpetuating the stereotypes of marriageability associated with the opposite sex. Several studies document both genders' dissatisfaction with the dominant cultural roles prescribed for the members of their own sex within marriage - but combined with a persistent aspiration for partners who would conform to these norms (e.g. Nemoto 2008; Nemoto et al. 2013).

The structural constraints that promote marriages as an exchange of gendered obligations, rather than an emotional bond, also diminish its value for personal fulfilment. Emotional 
closeness is hard to achieve if husbands and wives spend much of the time operating in separate spheres as overtime work and work-related socialising for men, and domestic responsibilities for women, add up to keep them apart.

\section{Reduced marriage pressure}

Given the widespread dissatisfaction with and perceived drawbacks of marriage, detailed above, why would Japanese singles desire marriage at all? Wishing to have a family, wishing to have children, cohabiting with a loved one, and not wishing to be alone in one's old age feature prominently for both men and women (MHLW 2013; NIPSSR 2015). This indicates that marriage remains the only way to secure life-long companionship with a non-relative. Wanting to reassure one's parents and relatives is also important, suggesting that marriage, to some extent, remains a family enterprise. While somewhat more women than men aged 20 to 39 note these reasons as important for them, the proportions of men and women choosing these answers are broadly similar (MHLW 2013).

Today marriage is hardly seen as "optional" in Japan, the way it is in many developed western countries, but the social pressure to marry by a particular age has declined significantly in recent decades (Nemoto et al. 2013; Yoshida 2016). This opens a loophole that enables Japanese singles to proclaim their desire to eventually form families, while postponing the actual family formation to some point in the future (see Ezawa, in this volume).

Given the structural constraints discussed above, for many singles marriage and childbearing seem both desirable and at the same time out of reach. In a 2014 survey of singles in seven OECD countries (Japan, South Korea, United States, UK, Germany, France, Sweden), the ratio of young people aged thirteen to twenty-nine who have the desire to be married and have children sooner than later was the second highest in Japan (following South 
Korea). The ratio of those who expected to actually be married and raising children by the time they are forty ranked the lowest (Cabinet Office, 2014).

\section{Discussion and Conclusion}

In recent decades Japan has undergone a number of changes in its family formation trends, such as later and fewer marriages, growing divorce rates, and fewer children. A cursory look suggests that attitudinal changes have followed suit. Marriages have been re-defined as a matter of personal choice rather than a familial institution, and there has been a clear liberalisation of attitudes to married women's participation in the labour market. A closer analysis of the available opinion polls reveals, however, that these were the only spheres where we observe individualisation and diversification of values related to family formation. We either see very limited change or a U-turn in attitudes related to marriage formation, many of which have been growing more conservative since the early 2000 s.

While men and women aspire to a more equal division of labour within marriages, the highly gendered labour market and the insufficient policies to support a work-family balance for husbands and wives continue to make these aspirations impractical. In these circumstances, an extreme division of labour, where the wife shoulders all the domestic work but does not have a stress of maintaining a career, seems to become more attractive to women. The worsening employment conditions for men, however, has led them to embrace the idea of working wives. At the same time, long working hours reduce husbands' ability to support these future wives' careers by helping with domestic work. This mismatch in marriage related aspirations has meant that single men and women remain open to the idea of marriage, and yet ambivalent when it comes to making the actual decision to marry and have a family. 
This analysis indicates that structural constraints on the realities of the "marriage package" in contemporary Japan play a major role in influencing individual attitudes to family formation. Marriages based on equal division of labour at home and in the labour market are favoured by men and women as an ideal family situation. There is, however, a major gap between perceptions of ideal and realistic family arrangements, and this gap can be traced back to the institutionalized labour market constraints. Further analysis using raw data is necessary to provide more detail exploring these findings.

\section{References}

Allison, A. (2000). Permitted and prohibited desires : mothers, comics, and censorship in Japan. Berkeley, Calif. ; London: University of California Press.

Bobrowska, S., \& Conrad, H. (2017). Discourses of Female Entrepreneurship in the Japanese Business Press - 25 Years and Little Progress. Japanese Studies, 37(1), 1-22.

Brinton, M. C., \& Mun, E. (2016). Between state and family: managers' implementation and evaluation of parental leave policies in Japan. Socio-Economic Review, 14(2), 257281.

Bumpass, L. L., Rindfuss, R. R., Choe, M. K., \& Tsuya, N. O. (2009). The institutional context of low fertility. Asian Population Studies, 5(3), 215-235.

Cabinet Office. (2014). Heisei 25 nendo waga kuni to shogaikoku no wakamono no ishiki ni kansuru chōsa. (Survey of young people's consciousness in Japan and other countries in 2013) Tokyo: Cabinet Office

Cook, E. E. (2013). Expectations of Failure: Maturity and Masculinity for Freeters in Contemporary Japan. Social Science Japan Journal, 16(1), 29-43.

Cook, E. E. (2014). Intimate expectations and practices: freeter relationships and marriage in contemporary Japan. Asian Anthropology, 13(1), 36-51. 
Cook, E. E. (2016). Reconstructing Adult Masculinities: Part-Time Work in Contemporary Japan. Abingdon: Routledge.

Dalton, E., \& Dales, L. (2016). Online Konkatsu and the Gendered Ideals of Marriage in Contemporary Japan. Japanese Studies, 36(1), 1-19.

Estévez-Abe, M. (2013). An international comparison of gender equality: Why is the Japanese gender gap so persistent? Japan Labor Review, 10(2), 82-100.

Fukuda, N. (2016). Marriage and fertility behaviour in Japan : economic status and valueorientation. Singapore: Springer.

Fukuda, S. (2013). The Changing Role of Women's Earnings in Marriage Formation in Japan. Annals of the American Academy of Political and Social Science, 646, 107-128.

Fuwa, M. (2014). Work-Family Conflict and Attitudes Toward Marriage. Journal of Family Issues, 35(6), 731-754.

Fuwa, M., \& Cohen, P. N. (2007). Housework and social policy. Social Science Research, $36(2), 512-530$.

Genda, Y., \& Hoff, J. (2005). A nagging sense of job insecurity: the new reality facing Japanese youth (1st English ed.). Tokyo, Japan: International House of Japan.

Gender Equality Bureau. (2017). White paper on gender equality (Danjo kyodou sankaku hakusho). Tokyo

Hertog, E. (2009). Tough Choices: Bearing an Illegitimate Child in Japan: Stanford University Press.

Hertog, E. (2018). Changes in childcare availability and parental time use between 1996 and 2016 in Japan. Paper presented at the IATUR 2018, Budapest.

Hertog, E., Kan, M.-Y., Shirakawa, K., \& Chiba, R. (2018). Do Better-Educated Couples Share Domestic Work More Equitably in Japan? It Depends on the Day of the Week. 
Discussion Paper Series from Institute of Economic Research. Hitotsubashi University.

Hidaka, T. (2010). Salaryman masculinity : the continuity of and change in the hegemonic masculinity in Japan. Leiden: Brill.

Honda, Y. (2002). Jenda to iu Kanten kara Mita 'Freeter' (Gender Approach to 'Freeter')'. In R. Kosugi (Ed.), Jiyu no Daisho: Freeter (The Cost of Freedom: Freeter) (pp. 149174). Tokyo: Nihon Roudou Kenkyu Kikou (The Japan Institute of Labour).

Japanese Economy Information Division. (2005). Child Day Care Industry in Japan.

Kamano, S. (2013). Women's Attitudes toward Marriage,Family and Gender Relationships since the 1990s in Japan: Analysis of Overtime Changes and Determining Factors. Journal of Population Problems, 69(1), 3-41.

Kaufman, G., \& Goldscheider, F. (2007). Do men "need" a spouse more than women? Perceptions of the importance of marriage for men and women. Sociological Quarterly, 48(1), 29-46.

Lee, K. S., Tufis, P. A., \& Alwin, D. F. (2010). Separate Spheres or Increasing Equality? Changing Gender Beliefs in Postwar Japan. Journal of Marriage and Family, 72(1), 184-201.

Lesthaeghe, R. (1983). A century of demographic and cultural change in Western Europe -an exploration of underlying dimensions. Population and Development Review, 9(3), 411-435.

Lesthaeghe, R. (2014). The second demographic transition: A concise overview of its development. Proceedings of the National Academy of Sciences of the United States of America, 111(51), 18112-18115. 
Matanle, P., Ishiguro, K., \& McCann, L. (2014). Popular Culture and Workplace Gendering among Varieties of Capitalism: Working Women and their Representation in Japanese Manga. Gender, Work \& Organization, 21(5), 472-489.

McDonald, P. (2000). Gender equity in theories of fertility transition. Population and Development Review, 26(3), 427-439.

McDonald, P. (2013). Societal foundations for explaining low fertility: Gender equity. Demographic Research, 28, 981-994.

MHLW. (2013). Heisei 25-nenban kōsei rōdō hakusho - wakamono no ishiki o saguru (2013 white paper on labour and welfare - understanding young poeple). Ministry of Health, Labour and Welfare

MHLW. (2014). Heisei 26-nendo kekkon kazoku keisei ni kansuru ishiki chōsa hōkoku-sho (Report of the 2014 survey on marriage family formation attitudes). Ministry of Health, Labour and Welfare

MHLW. (2016). Hoikujo-tō kanren jōkyō torimatome wo kōhyō shimasu (A summary of the situation of nurseries and related issues) [Press release] Ministry of Health, Labour and Welfare

MHLW. (various years). Demographic Statistics (Jinkō dōtai tōkei). Ministry of Health, Labour and Welfare

Mirza, V. (2016). Young Women and Social Change in Japan: Family and Marriage in a Time of Upheaval. Japanese Studies, 36(1), 21-37.

Nagase, N., \& Brinton, M. C. (2017). The gender division of labor and second births: Labor market institutions and fertility in Japan. Demographic Research, 36, 339-370.

Nemoto, K. (2008). Postponed marriage - Exploring women's views of matrimony and work in Japan. Gender \& Society, 22(2), 219-237. 
Nemoto, K. (2016). Too few women at the top: the persistence of inequality in Japan. Ithaca: ILR Press.

Nemoto, K., Fuwa, M., \& Ishiguro, K. (2013). Never-Married Employed Men's Gender Beliefs and Ambivalence Toward Matrimony in Japan. Journal of Family Issues, 34(12), 1673-1695.

NIPSSR. (2005). 13th basic survey of childbearing trends (Dai jugokai shussei dōkō kihon chōsa). National Institute of Population and Social Security Research

NIPSSR. (2010). 14th basic survey of childbearing trends (Dai jugokai shussei dōkō kihon chōsa). National Institute of Population and Social Security Research

NIPSSR. (2013). 5th national survey of family trends (Daigokai zenkoku katei dōkō chōsa). National Institute of Population and Social Security Research

NIPSSR. (2015). 15th basic survey of childbearing trends (Dai jugokai shussei dōkō kihon chōsa). National Institute of Population and Social Security Research

OECD. (2015). Japan Policy Brief [Press release].

OECD. (2017). Labour Force Statistics: indicators by sex and age.

Oppenheimer, V. K. (2003). Cohabiting and marriage during young men's careerdevelopment process. Demography, 40(1), 127-149.

Oppenheimer, V. K., Kalmijn, M., \& Lim, N. (1997). Men's career development and marriage timing during a period of rising inequality. Demography, 34(3), 311-330.

Piotrowski, M., Kalleberg, A., \& Rindfuss, R. R. (2015). Contingent Work Rising: Implications for the Timing of Marriage in Japan. Journal of Marriage and Family, 77(5), 1039-1056.

Raymo, J. M., \& Iwasawa, M. (2005). Marriage Market Mismatches in Japan: An Alternative View of the Relationship between Women's Education and Marriage. American Sociological Review, 70(5), 801-822. 
Raymo, J. M., \& Iwasawa, M. (2008). Changing Family Life Cycle and Partnership Transition - Gender Roles and Marriage Patterns. In F. Coulmas (Ed.), The demographic challenge: a handbook about Japan (pp. xix, 1199 p.). Leiden: Brill.

Retherford, R. D., Ogawa, N., \& Sakamoto, S. (1996). Values and Fertility Change in Japan. Population Studies, 50(1), 5-25.

Schoppa, L. J. (2006). Race for the exits: the unraveling of Japan's system of social protection. Ithaca, N.Y.; London: Cornell University Press.

Shirahase, S. (2014). Social inequality in Japan. Abingdon: Routledge.

Statiatics Bureau. (various years). Census.

Taga, F. (2017). Dilemma of fatherhood: The meaning of work, family, happiness for salaried male Japanese workers. In B. G. Holthus \& W. Manzenreiter (Eds.), Life course, happiness and well-being in Japan (pp. xvii, 280 pages). London: Routledge.

The Economist Data Team. (2016, Mar 3rd 2016). The best—and worst—places to be a working woman: the glass-ceiling index. The Economist.

Uchino, J., Iijima, A., \& Takahashi, T. (2013). An Analysis of Unmarried Men's Attitudes to Marriage and Family Focusing on Non-Regular Employees: Empirical Evidence from Survey Data. ESRI Discussion Paper Series. Cabinet Office. Tokyo.

Yoshida, A. (2016). Unmarried Women in Japan : The drift into singlehood. In Routledge Research on Gender in Asia Series (pp. 1 online resource (218 pages).

Yu, W.-H. (2009). Gendered trajectories : women, work, and social change in Japan and Taiwan. Stanford, Calif.: Stanford University Press.

Yu, W.-H., \& Hertog, E. (2018). Family Characteristics and Mate Selection: Evidence from Computer-Assisted Dating in Japan. Journal of Marriage and Family, 80(3), 589-606. 